\title{
The Relationship Between Geology and Landslide Hazards of Atchison, Kansas, and Vicinity
}

\author{
Gregory C. Ohlmacher \\ Kansas Geological Survey, 1930 Constant Avenue, Lawrence, Kansas 66047
}

\begin{abstract}
Landslides along the Missouri and Kansas rivers will affect existing structures and potential development in the Kansas City metropolitan area. A pilot landslide-mapping project was conducted in the vicinity of Atchison, Kansas, to inventory existing landslides and determine the factors that caused them. Landslides are generally controlled by the slope morphology, geology, soils, and moisture conditions. For this study, landslides were divided into recent and older landslides (including earth slides and earth flows) and rock-fall hazards (including rock falls and rock topples). Recent landslides are associated with shale members of the Pennsylvanian Lawrence Formation, Oread Limestone, Kanwaka Shale, and Tecumseh Shale. Limestone layers that occur between these shale members were incorporated into recent and older landslides. Recent landslides occurred on slopes with an average angle of 22 degrees. Recent landslides were also observed in glacial drift, loess, and alluvium. Rockfall hazards occurred in areas of nearly vertical slopes along streams, river bluffs, highways, and quarries, where limestone members of the Pennsylvanian Oread, Lecompton, and Deer Creek Limestones are exposed. Troublesome rock-fall hazards occurred where weak shale layers are eroding underneath resistant limestone layers.
\end{abstract}

\section{Introduction}

In 1995, a landslide destroyed two $\$ 400,000$ homes in Overland Park, Kansas, dramatically underscoring the need for landslide studies in the greater Kansas City metropolitan area. During reconnaissance mapping in 1997, landslides were located along the Missouri River from Kansas City to Wathena, along the Kansas River from Kansas City to Topeka, and along Stranger Creek from the Kansas River to Potter (fig. 1). Based on the reconnaissance and previous damaging landslides in Wyandotte and Johnson counties, a pilot project was initiated to study the landslide hazards of the Kansas City metropolitan area in Kansas.

The objectives of the pilot project were to produce a landslide inventory map (Ohlmacher, 2000) and a landslide susceptibility map for a region near the Kansas City metropolitan area. An inventory map shows the locations of landslides and related features, whereas a susceptibility map ranks the degree to which parts of the study area are prone to future landslides, based on the factors that produced past landslides. (A landslide susceptibility map does not provide information on how often landslides occur, as in a landslide hazard map, or the extent of damages and injuries that might be anticipated from a future landslide event, as in a landslide risk map.) A landslide event is defined as one or more landslides occurring during a limited time frame-for example, during and following a severe rainstorm. A landslide susceptibility map requires detailed information on the

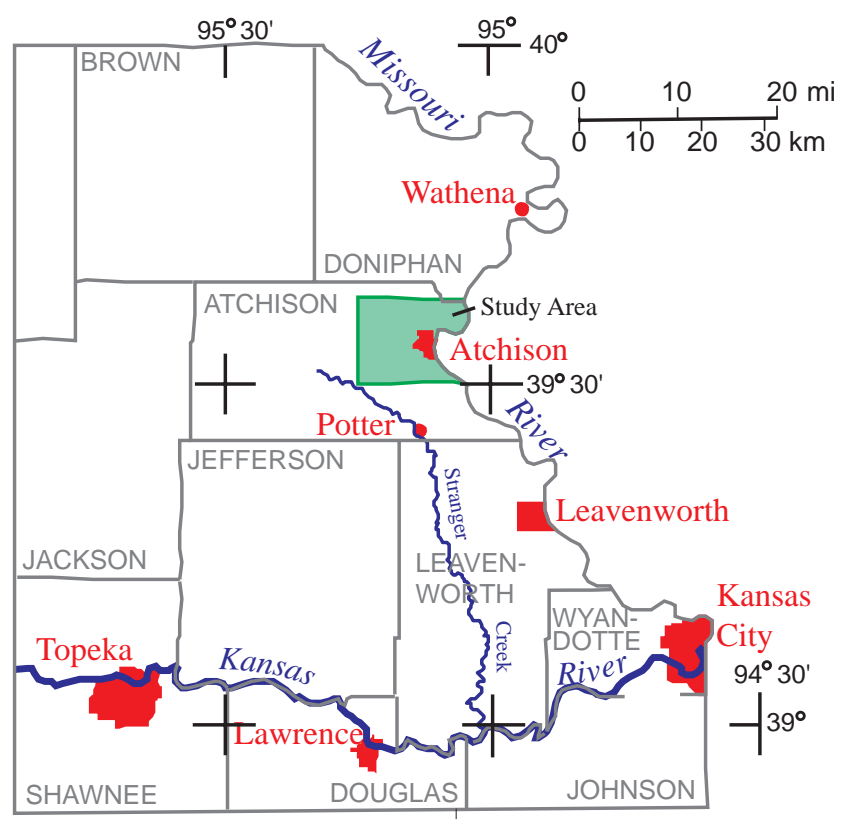

FIGURE 1. Map of northeast Kansas, showing the location of the study area (green shaded area) and locations mentioned in the text. 
factors causing landslides, including slope morphology, geology, and soils. This report presents information on the causal factors collected as part of the pilot study.

\section{Setting}

The area around Atchison, Kansas, was chosen as the study area for the pilot project because of its proximity to the Kansas City metropolitan area and the occurrence of landslides (fig. 1). Landslides around Atchison were observed during the 1997 reconnaissance mapping and were reported by a former Atchison city engineer ( $\mathrm{J}$. Hixon, personal communication, 1997). One of the reported landslides broke a sewer line south of downtown, and another landslide occurred behind a house near Jackson Park. A map showing the location of landslides and breaks in the sewer line between downtown and Jackson Park was produced by the City of Atchison (unpublished data, 1995). The map shows the locations of five sewer breaks that occurred during the last 10 years. It is not known how many breaks resulted from landslides.

Atchison is presently unaffected, or only marginally affected, by the growth of the Kansas City metropolitan area. Except for some growth in the 1920's and in the late 1990 's, both the city and county have seen a slow, steady decline in population, and this decline is projected to continue in the near future (Helyar, 1999). However, new homes being constructed in and to the south of Atchison suggest that growth may be on the rise.

The study area around Atchison lies within the Glaciated Region physiographic province, whereas Kansas
City straddles the boundary between the Glaciated Region and the Osage Cuestas. Although this might imply geologic differences between the two areas, the surficial geology around Atchison and Kansas City is fairly similar. The rocks at the surface in both areas consist of glacial drift, loess, bedrock, and alluvium, although the Kansas City area has less glacial drift and more bedrock. The topography of both Atchison and Kansas City is controlled by the Missouri River and its tributaries. Geologic similarities, the potential for population growth, and the proximity to Kansas City made Atchison a suitable location for the pilot project.

\section{Physiography}

The study area, which includes the entire City of Atchison and part of Atchison County, was defined as the area covered by the U.S. Geological Survey Atchison West and the Atchison East 7-1/2 minute topographic maps (excluding Missouri) (fig. 1). In general, the study area consists of an area of gently rolling hills to the west and a more rugged, hilly topography to the east, near the Missouri River. The total relief is about $112 \mathrm{~m} \mathrm{(370} \mathrm{ft),}$

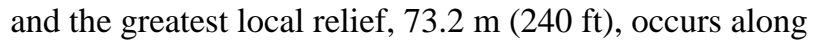
the bluffs of the Missouri River. The Missouri River and its tributaries-the Independence, White Clay, Brewery, Whiskey, Walnut, and Camp creeks_-drain the study area (fig. 2). Steep slopes occur in the bluffs along the Missouri River and its tributaries, where bedrock units of Pennsylvanian age are exposed. The glacial deposits in the western half of the study area have relatively gentle slopes.

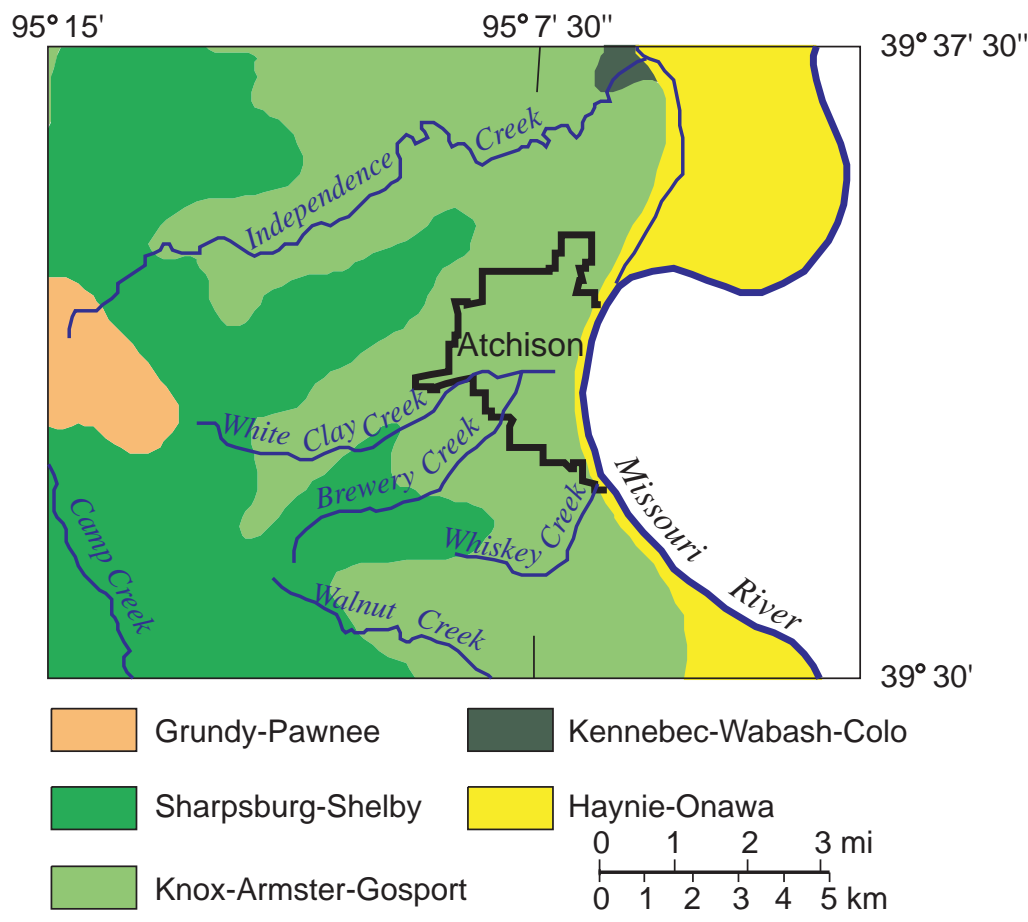

FIGURE 2. Map of the study area showing the soil associations as defined by the National Resources Conservation Service (Sallee and Watts, 1984). Soil associations are regions with similar soil series, slope morphology, and drainage characteristics. 


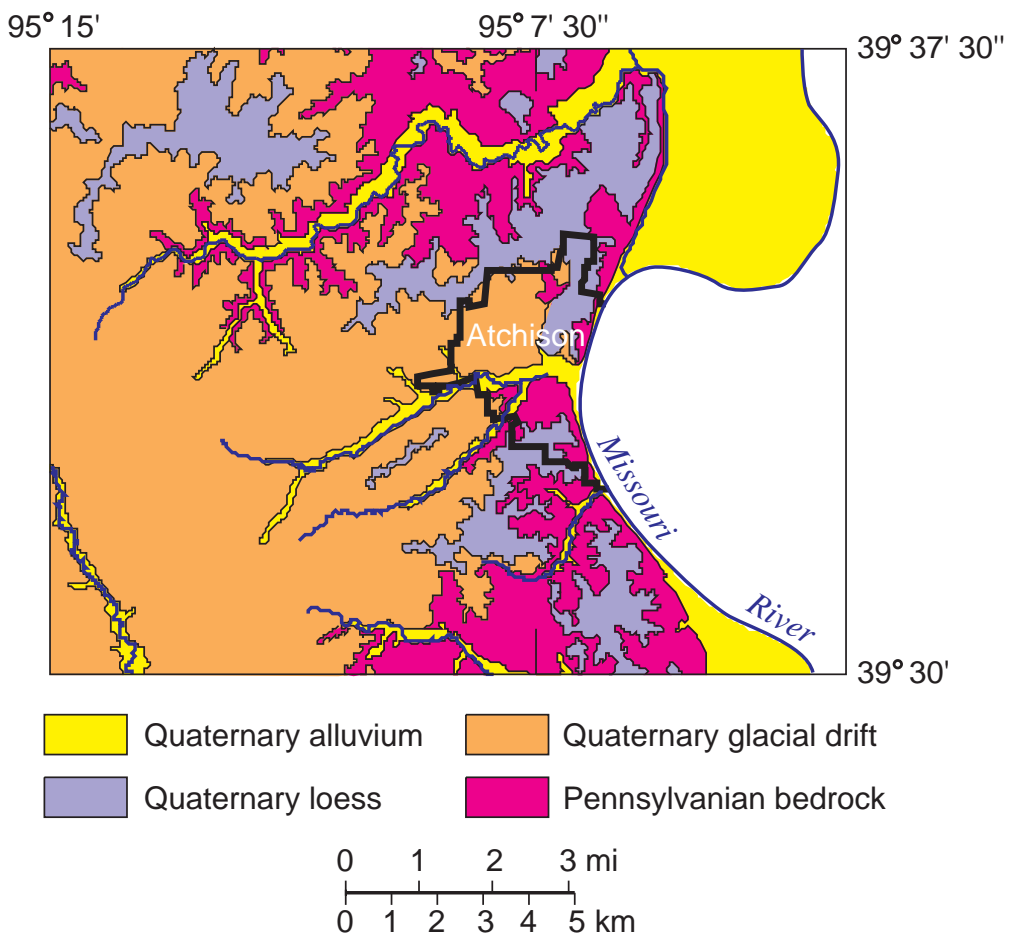

FIGURE 3. Generalized geologic map of the study area (from Ohlmacher, 1999).

\section{Soils}

Soil is defined differently by geologists and engineers. Whereas geologists (and pedologists) look at soils as the products of the weathering of rock and sediments, engineers consider soil to be a "relatively loose agglomerate of mineral and organic materials and sediments found above bedrock" (Holtz and Kovacs, 1981). This definition includes geologic soils, unconsolidated sediments, and rocks such as loess that can be easily excavated (Kehew, 1995; West, 1995). The engineer's definition of soil is commonly used in studying and describing landslides (Varnes, 1978) and will be used in this report.

The National Resources Conservation Service (NRCS) has published a soil survey of Atchison County that identifies the soil series present in the county and provides some data on soil properties (Sallee and Watts, 1984). A soil series is a class of soils with similar soil profiles including horizons, color, texture, structure, composition, and other properties. Sallee and Watts (1984) recognized 19 soil series in Atchison County. The units used on the detailed soil maps consist of one or more soil series. Additionally, Sallee and Watts (1984) divided Atchison County into seven soil associations based on patterns of soil series, slope, and drainage. Of the seven soil associations, five are found in the study area (fig. 2). These can be lumped into three groups: soils in gently rolling terrain, soils on hilly terrain, and lowland soils.

The western part of the county has gently rolling terrain that exposes soils of the Grundy-Pawnee and SharpsburgShelby associations. These are deep soils, developed on glacial drift and loess, on level to moderate slopes. Deep soils are those where bedrock is at least $152 \mathrm{~cm}$ (60 in) below the surface. The Sharpsburg-Shelby Association occurs in areas with slightly more relief than GrundyPawnee Association.

The Knox-Armster-Gosport Association is exposed in the hilly terrain in the central portion of the study area. This association consists of shallow to deep soils on strongly sloping to steep hillsides. Gosport Series are thinner and develop on bedrock, Armster Series develop on glacial drift, and Knox Series develop on loess. The Knox-Armster-Gosport Association also contains small areas of Vinland Series that develop on shales.

The lowland areas include the floodplains of the Missouri River and its tributaries. In this area, KennebecWabash-Colo and Haynie-Onawa associations are dominant. These are deep soils developed on alluvium, on level to gently sloping land.

\section{Geology}

The surficial geology of the study area includes bedrock, glacial drift, loess, and alluvium (fig. 3). The bedrock is Pennsylvanian in age and consists of layers of shale, siltstone, limestone, and sandstone (table 1). In general, bedrock is exposed in the bluffs along the Missouri River and its tributaries and in areas of hilly terrain. Glacial drift includes till, alluvium, and lakebeds deposited during the Pleistocene ice ages. An extensive area of glacial drift is found in the western portion of the study area. Loess, deposits of windblown silt and sand, can be found at the tops of hills in the central and eastern 


\section{Ohlmacher}

TABLE 1. Description of the geologic units, based on data from Price (1896), Condra (1927), Ward (1973), R. C. Moore (unpublished data), and author's field notes.

\begin{tabular}{lcc}
\hline \hline Age & Geologic unit & Thickness \\
& m (ft) & Description \\
\hline
\end{tabular}

$\mathbf{m}(\mathbf{f t})$

\begin{tabular}{|c|c|c|c|}
\hline \multirow[t]{4}{*}{ Quaternary } & alluvium & $0-32(0-105)$ & $\begin{array}{l}\text { Tan, brown, and gray silt, sand, and } \\
\text { gravel }\end{array}$ \\
\hline & loess & $0-12.2(0-40)$ & $\begin{array}{l}\text { Gray, clayey, sandy silt that weathers } \\
\text { yellow to brown }\end{array}$ \\
\hline & glacial drift & highly variable & $\begin{array}{l}\text { This unit includes glacial till (gray, poorly } \\
\text { sorted clay to boulders that weather brown) } \\
\text { outwash deposits (tan to brown sand and } \\
\text { gravel), and the "Nortonville clay" (gray to } \\
\text { brown silty clays) }\end{array}$ \\
\hline & Atchison formation & $0-24.3(0-80)$ & Tan to gray, silty sand to gravel \\
\hline
\end{tabular}

\begin{tabular}{|c|c|c|c|}
\hline \multirow[t]{15}{*}{ Pennsylvanian } & $\begin{array}{l}\text { Topeka Limestone } \\
\text { Hartford Limestone Member }\end{array}$ & $1.2(3.8)$ & $\begin{array}{l}\text { Gray, massive limestone that weathers } \\
\text { yellow-brown }\end{array}$ \\
\hline & Calhoun Shale & $5.2(17)$ & $\begin{array}{l}\text { Gray, bluish- to greenish-gray, blocky to } \\
\text { flaggy, interbedded siltstone and shale that } \\
\text { weathers yellow-brown }\end{array}$ \\
\hline & $\begin{array}{l}\text { Deer Creek Limestone } \\
\text { Ervine Creek Limestone } \\
\text { Member }\end{array}$ & $5.2(17)$ & $\begin{array}{l}\text { Gray to tan, wavy-bedded to } \\
\text { massive limestone that weathers } \\
\text { yellow-brown }\end{array}$ \\
\hline & Larsh-Burroak Shale Member & $1.5(4.8)$ & $\begin{array}{l}\text { Gray siltstone and shale, overlying } \\
\text { black shale, siltstone, and coal }\end{array}$ \\
\hline & Rock Bluff Limestone Member & $0.6(1.9)$ & $\begin{array}{l}\text { Light- to medium-gray, massive limestone } \\
\text { that weathers yellow-brown }\end{array}$ \\
\hline & Oskaloosa Shale Member & $2.3(7.6)$ & $\begin{array}{l}\text { Gray siltstone and shale with gray } \\
\text { sandstone layers }\end{array}$ \\
\hline & Ozawkie Limestone Member & $0.9(3)$ & $\begin{array}{l}\text { Gray, massive limestone that weathers yellow- } \\
\text { brown }\end{array}$ \\
\hline & Tecumseh Shale & $19.8(65)$ & $\begin{array}{l}\text { Gray to green-gray, interbedded shale and } \\
\text { siltstone with yellow to tan sandstone }\end{array}$ \\
\hline & $\begin{array}{l}\text { Lecompton Limestone } \\
\text { Avoca Limestone Member }\end{array}$ & $0.4(1.2)$ & $\begin{array}{l}\text { Dark blue-gray limestone that weathers } \\
\text { yellow-brown }\end{array}$ \\
\hline & King Hill Shale Member & $1.9(6.2)$ & Bluish-gray silty shale \\
\hline & Beil Limestone Member & $1.6(5.2)$ & $\begin{array}{l}\text { Gray, shaly limestone that weathers } \\
\text { yellow-brown }\end{array}$ \\
\hline & Queen Hill Shale Member & $1.5(4.8)$ & $\begin{array}{l}\text { Blue-gray, silty shale overlying black, } \\
\text { fissile shale }\end{array}$ \\
\hline & $\begin{array}{l}\text { Big Springs Limestone } \\
\text { Member }\end{array}$ & $0.8(2.6)$ & $\begin{array}{l}\text { Gray to tan, massive limestone that } \\
\text { weathers yellow-brown }\end{array}$ \\
\hline & Doniphan Shale Member & $1.9(6.1)$ & $\begin{array}{l}\text { Bluish-gray, bedded, silty to calcareous } \\
\text { shale that weathers yellow-brown }\end{array}$ \\
\hline & $\begin{array}{l}\text { Spring Branch Limestone } \\
\text { Member }\end{array}$ & $1.4(4.7)$ & $\begin{array}{l}\text { Two, gray to tan, massive limestone layers that } \\
\text { weather yellow-brown, separated by a thin (15- } \\
\mathrm{cm}) \text {, gray to tan shale; the shale may be absent }\end{array}$ \\
\hline
\end{tabular}


TABLE 1, cont.

\begin{tabular}{|c|c|c|c|}
\hline Age & Geologic unit & $\begin{array}{l}\text { Thickness } \\
\text { m (ft) }\end{array}$ & Description \\
\hline & $\begin{array}{l}\text { Kanwaka Shale } \\
\text { Stull Shale Member }\end{array}$ & $11.1(36.4)$ & $\begin{array}{l}\text { Gray, bluish-gray to greenish-gray siltstone and } \\
\text { shale and tan to gray sandstone; a } \\
\text { discontinuous coal or black shale may } \\
\text { exist above the sandstone; in some areas, } \\
\text { the base is } 20 \text {-cm ( } 8 \text {-in) clay }\end{array}$ \\
\hline & $\begin{array}{l}\text { Clay Creek Limestone } \\
\text { Member }\end{array}$ & $0.8(2.7)$ & $\begin{array}{l}\text { Gray, massive limestone that weathers yellow- } \\
\text { brown; the top may be marked by a red, thin, } \\
\text { shaly limestone }\end{array}$ \\
\hline & $\begin{array}{l}\text { Jackson Park Shale } \\
\text { Member }\end{array}$ & $1.9(6.1)$ & $\begin{array}{l}\text { Gray, bluish-gray to green-gray, thinly bedded } \\
\text { siltstone and shale with some sandstone layers; } \\
\text { the brown unit weathers tan to brown }\end{array}$ \\
\hline & $\begin{array}{l}\text { Oread Limestone } \\
\text { Kereford Limestone Member }\end{array}$ & $0.8(2.6)$ & $\begin{array}{l}\text { Gray limestone; thin or absent in parts of the } \\
\text { study area }\end{array}$ \\
\hline & Heumader Shale Member & $1.4(4.7)$ & $\begin{array}{l}\text { Gray to greenish-gray shale and silty shale } \\
\text { that weathers brown }\end{array}$ \\
\hline & $\begin{array}{l}\text { Plattsmouth Limestone } \\
\text { Member }\end{array}$ & $6.2(20.5)$ & $\begin{array}{l}\text { Medium- to dark-gray, wavy-bedded limestone } \\
\text { that weathers light-gray to light yellow-brown }\end{array}$ \\
\hline & Heebner Shale Member & $1.4(4.5)$ & $\begin{array}{l}\text { Dark-gray, fissile to platy shale and silty shale, } \\
\text { overlying black fissile to platy shale }\end{array}$ \\
\hline & $\begin{array}{l}\text { Leavenworth Limestone } \\
\text { Member }\end{array}$ & $0.5(1.7)$ & Dark-gray, massive limestone \\
\hline & Snyderville Shale Member & $3.8(12.5)$ & Gray shale and silty shale \\
\hline & Toronto Limestone Member & $2.3(7.5)$ & $\begin{array}{l}\text { Light-gray to yellow-gray, massive } \\
\text { limestone that weathers yellow-brown }\end{array}$ \\
\hline & Lawrence Formation & $7.6+(25+)$ & Green-gray shale, red beds, and coal \\
\hline
\end{tabular}

portions of the study area. Alluvial deposits occur along the Missouri River and its tributaries.

The following descriptions of the geologic units are based on published reports (Price, 1896; Condra, 1927; and Ward, 1973). Additional data came from measured sections by R. C. Moore (unpublished data) and the author.

\section{Douglas Group}

The oldest formation exposed in the study area is the Lawrence Formation. Only the upper portion of the Lawrence Formation is exposed along the base of the Missouri River Bluffs in the southeastern portion of the study area. The Lawrence Formation is composed of gray shales, red beds, and coal (table 1).

\section{Shawnee Group}

The Oread Limestone overlies the Lawrence Formation. The Oread Limestone is approximately $16.4 \mathrm{~m} \mathrm{(54 \textrm {ft } )}$ thick and consists of limestone layers separated by shales and siltstones (table 1). The formation is exposed along the lower parts of the Missouri River bluffs and the bluffs of its tributaries in the eastern part of the study area. The thickest limestone of the Oread is the Plattsmouth Limestone Member, which is approximately $6.2 \mathrm{~m}$ (20.5 $\mathrm{ft}$ ) thick. The Plattsmouth Member is mined by quarrying and underground mining for aggregate and industrial uses (fig. 4). Several sinkholes have opened above an abandoned underground mine north of the city of Atchison, and subsidence above abandoned underground mines is a problem in the study area.

The Kanwaka Shale forms a gentle slope between the Oread Limestone and the overlying Lecompton Limestone in the central and eastern portions of the study area. The Kanwaka Shale is approximately $17.8 \mathrm{~m}(58.4 \mathrm{ft})$ thick and is composed of two gray shale and siltstone members separated by the Clay Creek Limestone Member (table 1). The Stull Shale Member, the upper shale and siltstone member, contains sandstone and a discontinuous coal layer. Exposures of the Kanwaka Shale are limited to highway outcrops (fig. 5) and areas where streams are eroding the base of the hills. 


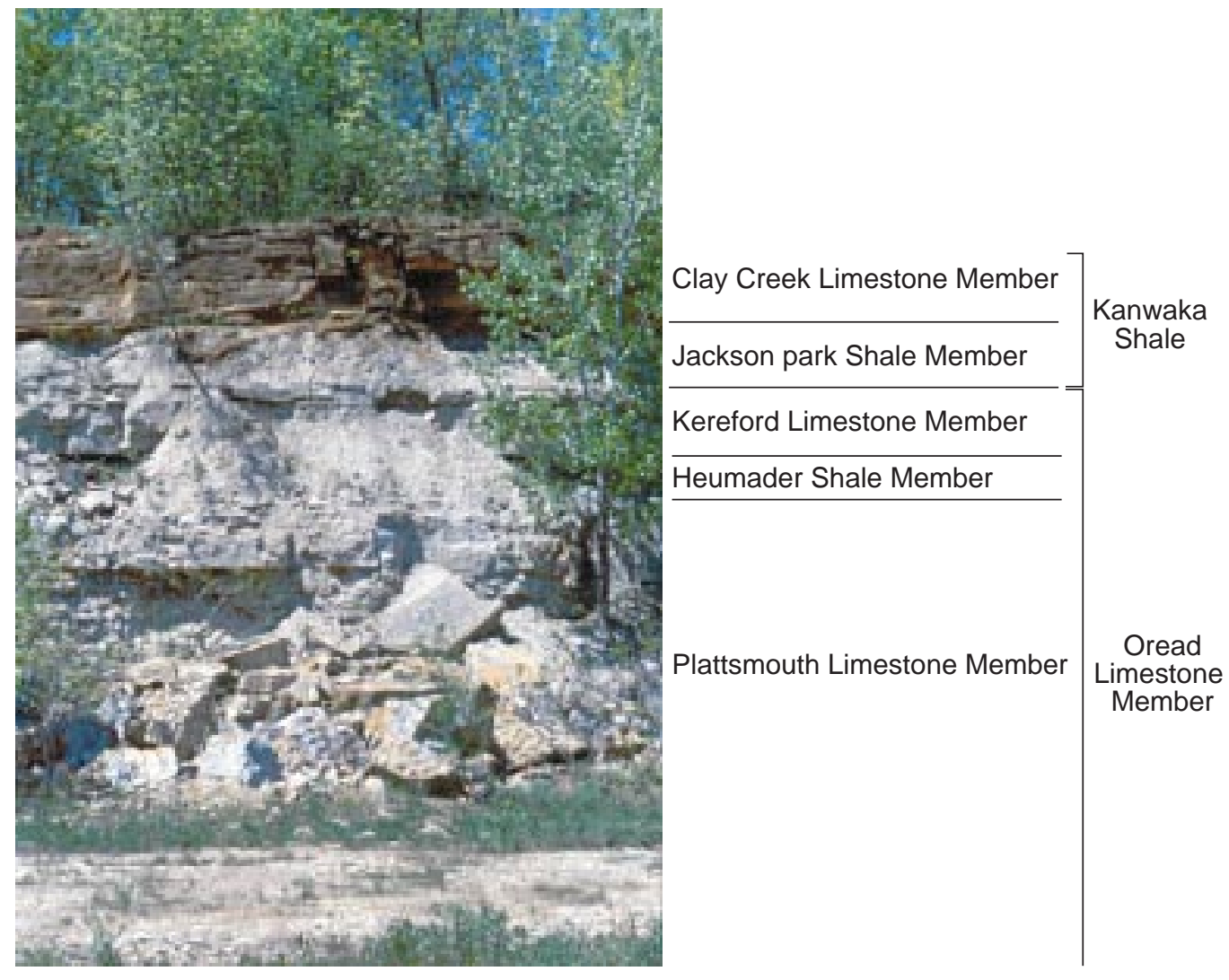

FIGURE 4. Upper part of the Oread Limestone and the lower part of the Kanwaka Shale, exposed in a quarry in the SW SW sec. 21, T. 6 S., R. 21 E.

The Lecompton Limestone is not well exposed in the study area. However, individual limestone layers are observed in many locations. The Lecompton Limestone forms a steep slope above the Kanwaka Shale. Ward (1973) stated that the Lecompton Limestone in Atchison County is from 10.7 to $13.7 \mathrm{~m}$ (35 to $45 \mathrm{ft}$ ) thick. The formation is composed of four limestone members separated by gray calcareous shales and siltstone (table 1). A black shale layer overlies the Big Springs Limestone Member. The basal Spring Branch Limestone Member can be seen below the trees in figure 5 .

The Tecumseh Shale forms a gentle slope between the Lecompton Limestone and the overlying Deer Creek Limestone in the central portion of the study area. The Tecumseh Shale is approximately $19.8 \mathrm{~m}(65 \mathrm{ft})$ thick and consists of gray shale and siltstone and yellow to tan sandstone layers (table 1). Several exposures of the Tecumseh Shale can be found along US-73 in the southern portion of the study area.

The Deer Creek Limestone forms a steep slope on the hillsides between the Tecumseh and Calhoun shales in the central portion of the study area. The formation is $10.5 \mathrm{~m}$ $(34.3 \mathrm{ft})$ thick and is composed of gray to bluish-gray limestone, gray shale and siltstone, black shale, sandstone, and minor amounts of coal (table 1). The thickest limestone is the Ervine Creek Limestone Member, which is $5.2 \mathrm{~m} \mathrm{(17.0} \mathrm{ft)} \mathrm{thick.} \mathrm{The} \mathrm{Ervine} \mathrm{Creek} \mathrm{Member} \mathrm{is}$ quarried for aggregate and industrial uses.

The Calhoun Shale overlies the Deer Creek Limestone and is below the Topeka Limestone. The Calhoun Shale is only exposed in a few areas in the northwest portion of the study area. The Calhoun Shale is approximately $5.2 \mathrm{~m}$ $(17.0 \mathrm{ft})$ thick and consists of alternating thin (centimetersthick) layers of gray shale and gray to tan siltstone and sandstone (table 1).

The basal Hartford Limestone Member of the Topeka Limestone is the uppermost bedrock unit exposed in the study area. The Hartford is a gray, massive limestone that

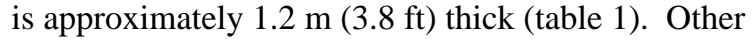
members of the Topeka Limestone exist below the glacial drift in the western part of the study area.

\section{Quaternary Sediments}

The Quaternary geology of the study area includes the Atchison formation (Moore et al., 1951), glacial drift, loess, and alluvium (Ohlmacher, 1999). An older glacial till (Frye, 1941) is exposed at stream level along White Clay Creek west of Atchison (fig. 6).

The Atchison formation is alluvium comprising tan to gray sand and gravel (table 1, fig. 6); it ranges in thickness from 0 to $24.3 \mathrm{~m}$ ( 0 to $80 \mathrm{ft}$ ). The unit is below the glacial drift and rests unconformably on bedrock and the older 


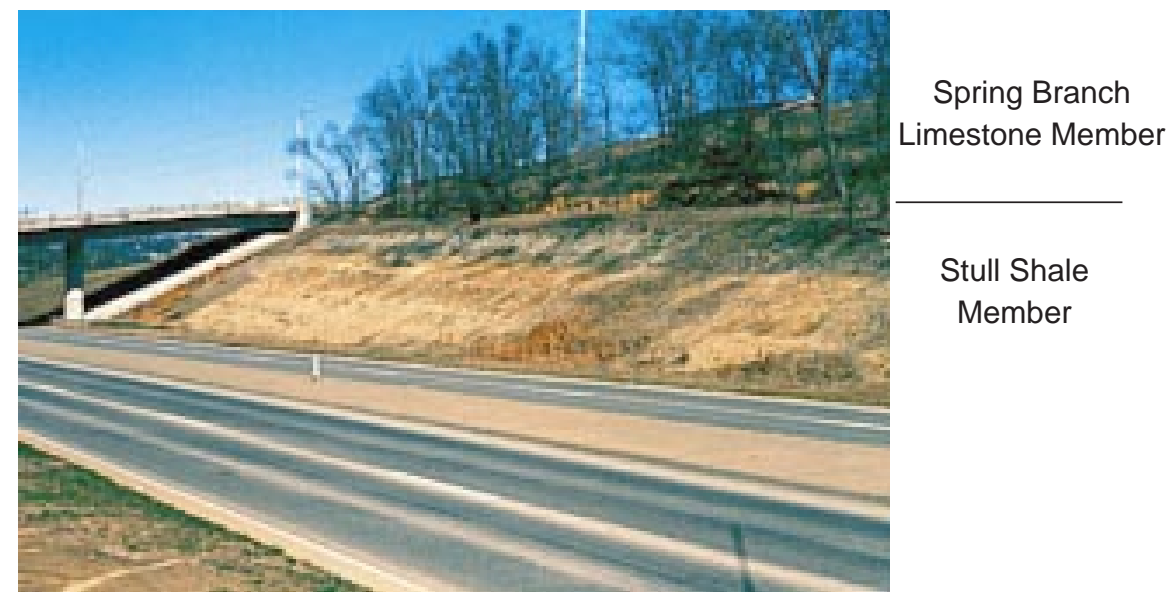

Figure 5. The Stull Shale Member of the Kanwaka Shale and the Spring Branch Limestone Member of the Lecompton Limestone, exposed in a roadcut along US-73 south of Atchison (SW SE sec. 1, T. 6 S., R. 20 E.)

glacial till. Exposures of the Atchison formation occur mainly along White Clay Creek.

The glacial drift rests unconformably on top of Pennsylvanian bedrock and the Atchison formation throughout the study area. Glacial drift dominates the western portion of the study area and can be found on most hilltops in the east (fig. 3). Drift includes glacial till, outwash, and lakebeds. The tills are gray to reddishbrown, poorly sorted, ice-transported sediments. Bouldersized fragments were observed in fields in the drift area. The outwash deposits are tan to brown, sandy to gravelly alluvium. The "Nortonville clay" (Frye and Leonard,
1952) was mapped with the glacial drift. The "Nortonville clay" is gray clay with some silt that was deposited above the till. Frye and Leonard (1952) proposed that this unit was deposited in ice-marginal lakes and lakes in depressions on the till surface.

Aber (1991) combined the older unmapped till, the Atchison formation, and the glacial drift into one unit. This unit, called the Independence formation, represents two pre-Illionoian glacial advances.

Loess can be found along hilltops in various locations throughout the study area (fig. 3). The loess is gray, clayey silt, with a little sand; it weathers yellow brown to

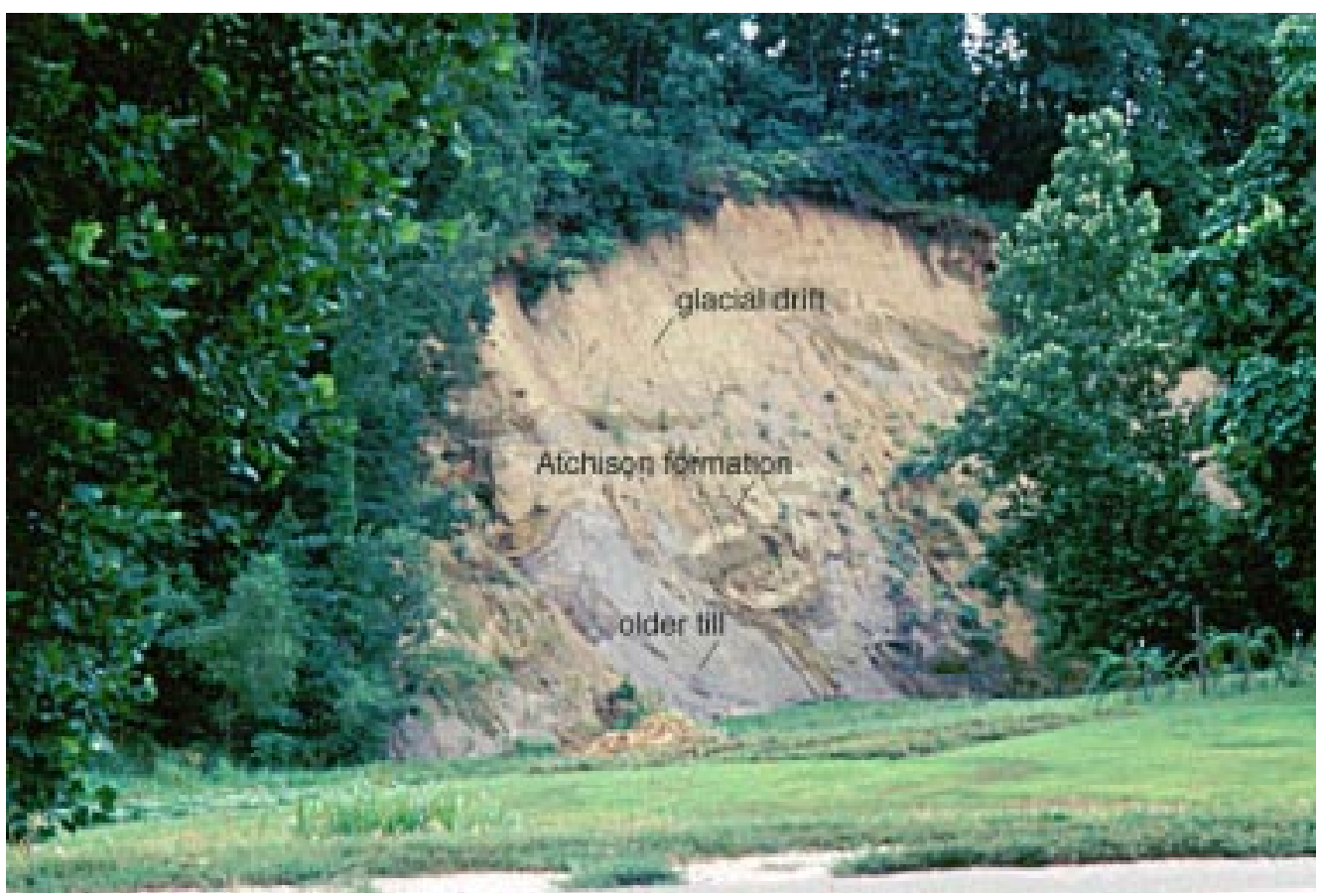

FIGURE 6. Exposure of the Atchison formation along White Clay Creek west of Atchison (SE NW sec. 10, T. 6 S., R. 20 E.). The older till and Atchison formation were deformed by the later glacial event that deposited the glacial drift. At this location, the drift is a younger till. For more information on this outcrop, see Aber (1991). 


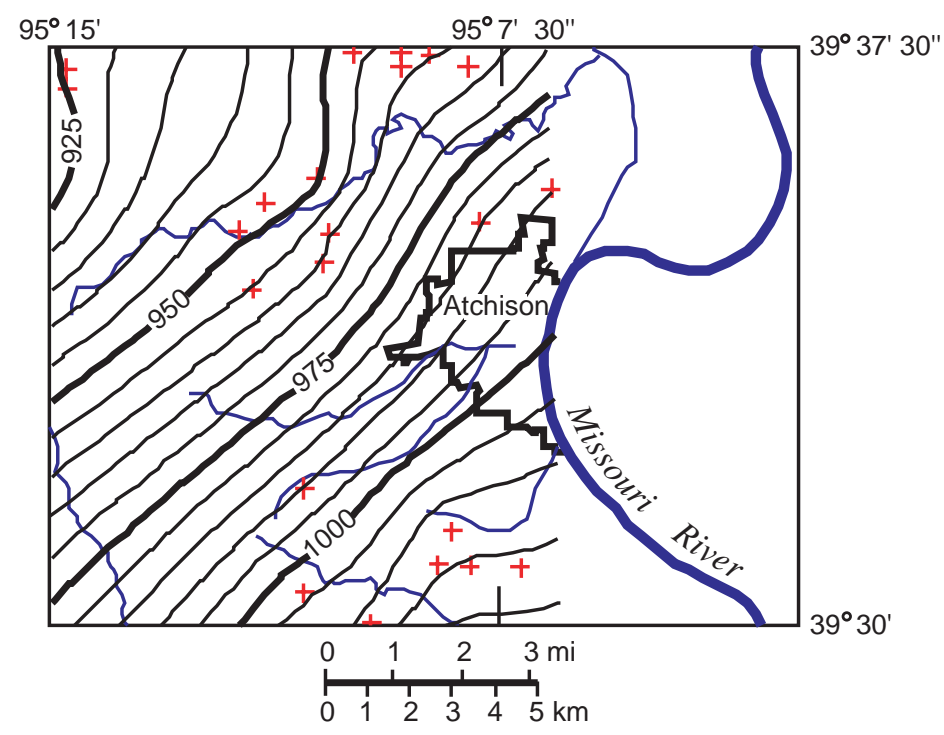

FIGURE 7. Structural contour map of the study area on the base of the Deer Creek Limestone. Red crosses represent the data points used to generate contours. Additional data points outside the study area were used and are not shown in the figure. There are no outcrops of the Deer Creek Limestone east of Atchison, and a pre-glacial river channel removed the Deer Creek Limestone due west of Atchison (Dreeszen and Burchett, 1971).

brown (table 1) and ranges in thickness from 0 to $12.2 \mathrm{~m}$ (0 to $40 \mathrm{ft}$ ).

Quaternary alluvium can be found along the Missouri River and its tributaries (fig. 3). It is composed of channel sand and gravel and floodplain silt (table 1). The thickness of the Quaternary alluvium ranges from 0 to $32.0 \mathrm{~m}$ ( 0 to $105 \mathrm{ft}$ ) (Ward, 1973).

\section{Structure}

No major faults or folds are observed in the study area. The Pennsylvanian bedrock generally dips gently to the northwest or west at about $3 \mathrm{~m} / \mathrm{km}(16 \mathrm{ft} / \mathrm{mi})$, although this varies slightly throughout the study area (fig. 7). Ward (1973) reports a southwesterly dip on the base of the Oread Limestone north of Atchison.

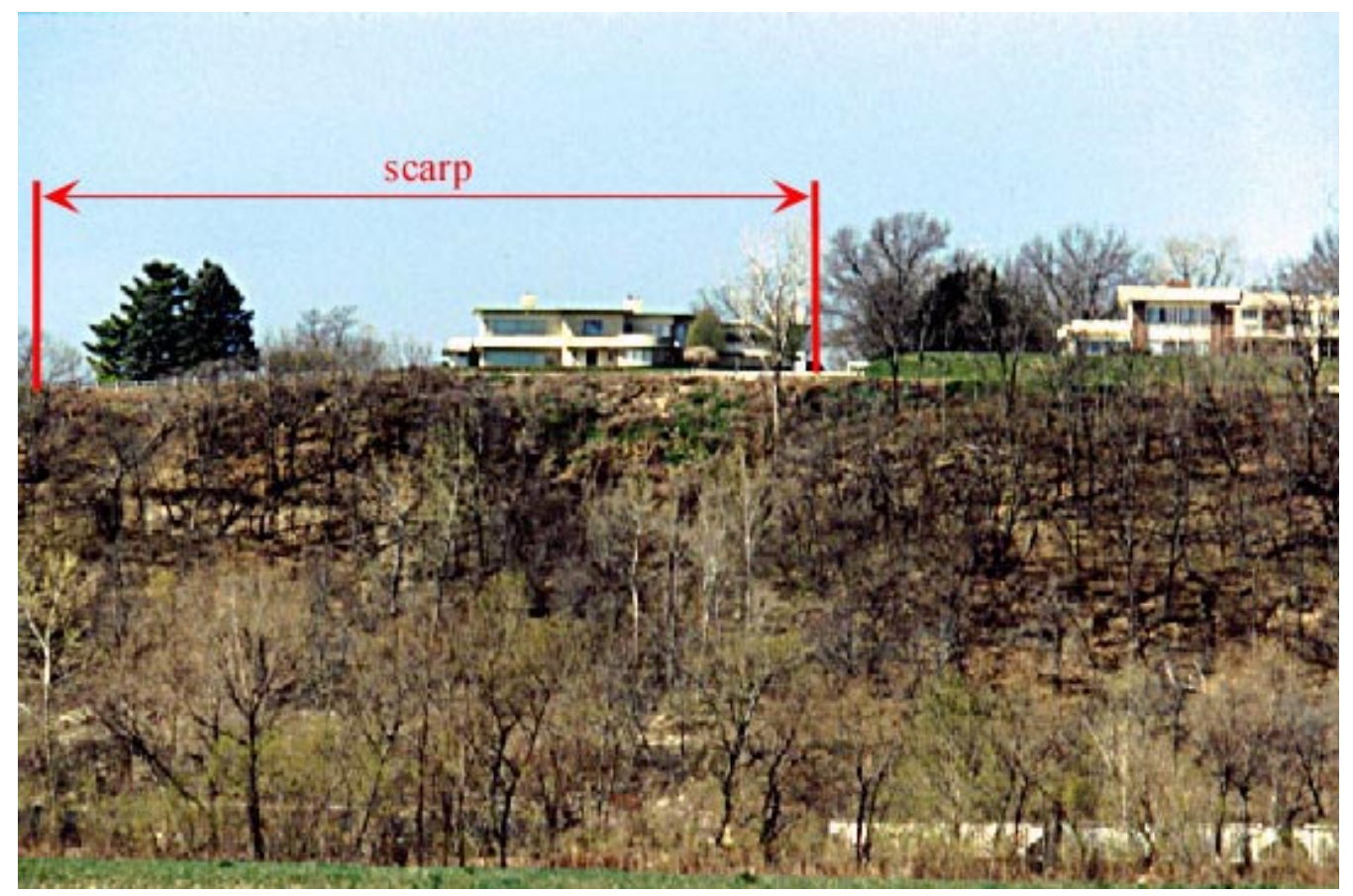

FIGURE 8. A recent landslide along Riverview Drive south of downtown Atchison (SW NE sec. 7, T. 6 S., R. 21 E.). The scarp (the surface break at the top of the landslide) is along the road at the top of the hill, and the toe (where material piles up at the bottom of the landslide) is at the base of the slope. The houses in the photograph are set back from the top of the hill and are not currently involved in the landslide. 


\section{Landslide Hazards}

Damaging landslides have occurred in the Atchison area. A 1997 landslide in the city of Atchison, along Riverview Drive (fig. 8), damaged the street at the top of the hill (fig. 9) and broke a sewer line along the base of the slope. This landslide has been active intermittently since 1959 (Zey and Ferguson, 1995). The houses visible above the landslide (fig. 8) were not affected by the landslide. Another landslide in 1997 occurred adjacent to a house. The house was not visibly damaged, but the scarp (the ground-surface break at the top of the landslide) was along the foundation of the house. Field mapping and aerial photographic interpretation revealed 145 recent landslides, along with rock-fall hazards and other landslide features.

\section{General features of Landslides}

A landslide is defined as a down-slope movement of a mass of soil, rock, and other material (Cruden, 1991). This broad definition includes a variety of failure modes and is not limited to slow-moving, slide-type failures. Mass movement (Sharpe, 1938), mass wasting (Thornbury, 1954), and slope movement (Varnes, 1978) are alternate terms for landslides as broadly defined. Currently, engineering geologists use landslide to cover all types of mass movement, and that usage will be followed in this report.

This report uses the landslide classification developed for the Transportation Research Board (Cruden and Varnes, 1996; Varnes, 1978), which subdivides landslides into material type and movement type. The material types are rock, debris, and earth. Rock is any material that requires blasting or splitting prior to removal; in the study area, rock consists primarily of layers of limestone. Debris is soil in which the average grains are sand-sized or larger, and earth is soil in which the average grain size is silt and smaller.

Four types of movement are found in the study areafalls, topples, flows, and slides. Falls occur where blocks of rock or soil break free and drop vertically before hitting the ground surface (fig. 10a). Topples occur where blocks of rock or soil rotate or pivot about an axis at the base of the block (fig. 10b). Both falls and topples are common in areas where layers of limestone overlay shales and siltstones (fig. 4). The shales and siltstones erode from beneath the limestones leaving unsupported blocks. Slides occur where a mass of soil or rock moves along a planar surface at the base of the landslide (fig. 10c). The material within the landslide mass may rotate but remains relatively intact during failure. Flows (fig. 11) occur where a mass of soil moves above a planar surface; however, the movement is distributed throughout the landslide mass approaching a fluidlike motion (fig. 10d). Earth slides, earth flows, and combinations of the two types are common throughout the study area.

A landslide inventory map was prepared for the study area (Ohlmacher, 2000). This map depicts recent

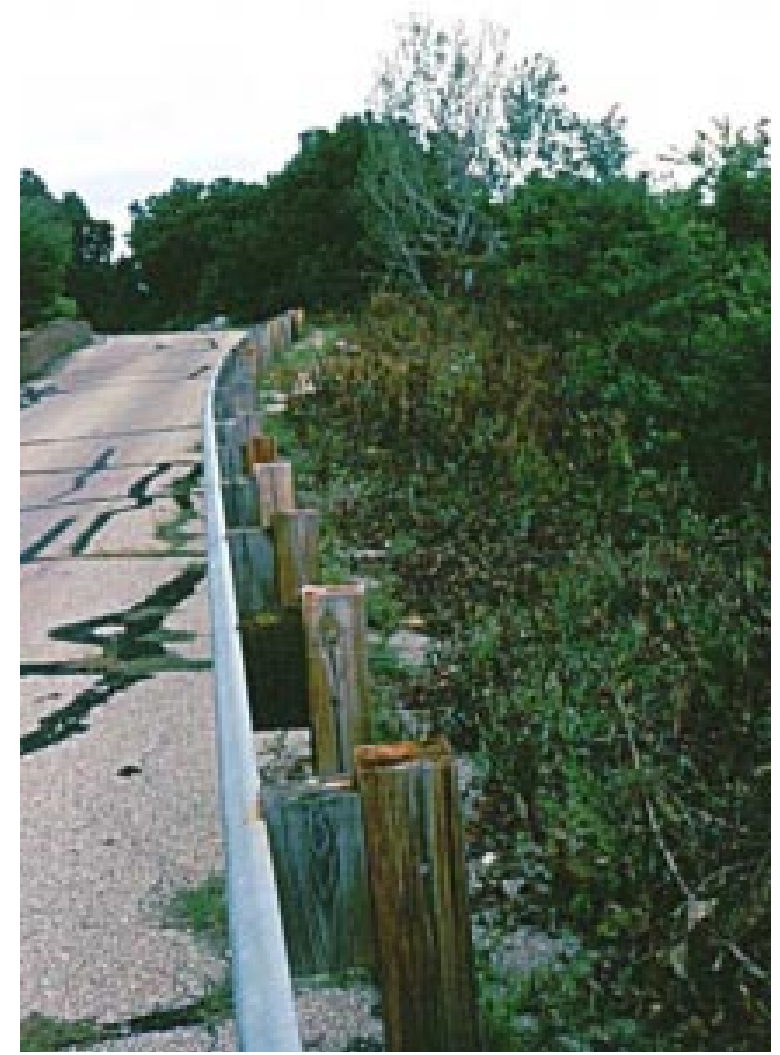

FIGURE 9. Scarp of the recent landslide along Riverview Drive (see fig. 8). The landslide has removed one lane from the street.

landslides, older landslides, and rock-fall hazards. Recent landslides are earth slides and earth flows with distinct features and clearly defined boundaries. These landslides include active landslides that had moved within a year of the study, along with suspended and dormant landslides that still had recognizable ground breaks. Older landslides had hummocky topography that indicated past landslide movement, but they lacked fresh surface breaks and clearly defined boundaries. Older landslides include dormant, relic, and ancient earth slides and earth flows as defined by Cruden and Varnes (1996).

Rock-fall hazards are nearly vertical exposures of rock where the potential for rock falls and rock topples is high. Rock-fall hazards occur in quarries (fig. 4), in highway cuts, along the bluffs of the Missouri River and its tributaries, and where streams have eroded into the base of hills exposing bedrock. It should be noted that some of the newer highway cuts made by the Kansas Department of Transportation are designed to minimize rock-fall hazards (fig. 5). Individual rock falls were not mapped as part of the project.

\section{Triggering mechanisms}

A triggering mechanism is an external stimulus that initiates the movement of a landslide (Wieczorek, 1996). Examples of triggering mechanisms include precipitation, 
(A)

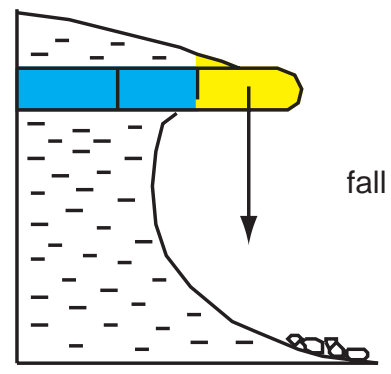

(B)

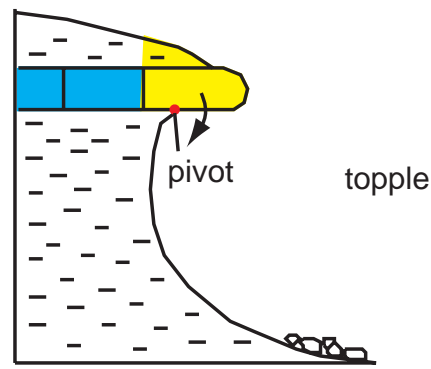

(C)

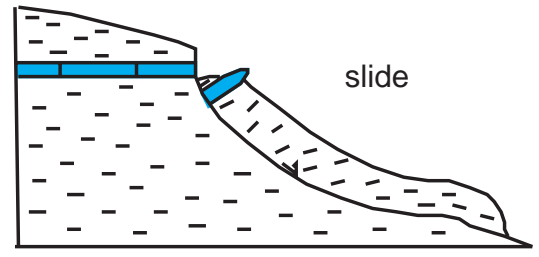

(D)

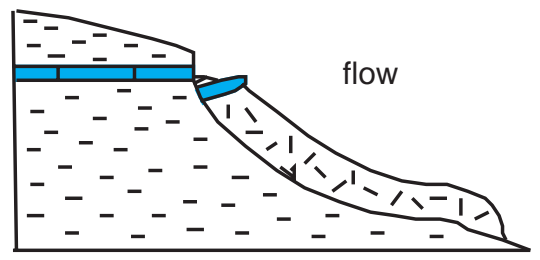

FIGURE 10. Different types of landslide movement. (A) Falls occur where a block of material free-falls from a slope. (B) Topples involve rotation of a block of material along an axis at the base of the block. (C) Slides occur where a relatively intact mass of material moves along a basal failure plane. (D) Flows occur where motion is distributed throughout the landslide mass approaching fluid-like behavior.

changes in ground-water levels, snowmelt, stream erosion, and earthquake shaking. Carson (1976) referred to these mechanisms as short-term triggers. Varnes (1978)

observes that landslides can have only one trigger but numerous causal factors. Causal factors are defined as conditions that contribute to instability but may not initiate failure. Carson (1976) referred to causal factors as longterm triggers, and his list included slope angle, weak soil and rock units, weathering, mass-movement history, and deconsolidation. Deconsolidation is the expansion of soil or rock due to unloading or stress relief. Human activities such as excavations and loading of slopes can either be triggering mechanisms or causal factors depending on other slope conditions. For example, if a trench fails following excavation with no other external stimulus, then the excavation was the triggering mechanism. However, if the trench is open for several days and fails during a rainstorm, then the excavation contributed to the failure and was a causal factor.

The primary focus of this study was to determine landslide susceptibility by examining the causal factors. The triggering mechanisms for landslides in the Atchison study area were not determined as part of this study. Triggering mechanisms are very important in studies of the initiation of individual landslides and in determining the probability of future landslides.

\section{Causal factors controlling slope stability}

Data from recent landslides-combined with geologic maps, NRCS soil maps, and topographic maps-were used to identify the causal factors for earth slides and earth flows. Rock-fall hazards were not incorporated in this study because they were previously mapped on the landslide inventory map (Ohlmacher, 2000). Rock and soil type, slope angle, and slope line-_"an imaginary line on the ground surface indicating the direction of steepest gradient at a given point, and therefore intersecting the contour lines at right angles" (Jackson, 1997, p. 599)— were the causal factors examined in this study.

\section{Geology and landslides}

Earth slides and earth flows tend to occur in finegrained materials such as shale and unconsolidated alluvium. In the study area, the geologic units with the majority of the recent landslides were the Kanwaka Shale (57 landslides), glacial drift (30), the Oread Limestone (28), the Lawrence Formation (23), and the Tecumseh Shale (17) (table 2). However, these numbers are misleading because they do not take into account the extent of each unit's exposure in the study area. For example, glacial drift is exposed over $98.78 \mathrm{~km}^{2}(38.41$ $\left.\mathrm{mi}^{2}\right)$, whereas the Lawrence Formation only is exposed over $0.39 \mathrm{~km}^{2}\left(0.15 \mathrm{mi}^{2}\right)$. When the 23 landslides that occurred in the Lawrence Formation are divided by the area of exposure, the number of landslides per unit area is 59 (table 2). This number is a better indicator of a geologic formation's susceptibility-Lawrence Formation (59) and glacial drift (0.3) — than the number of landslides taken alone.

The geologic unit in the study area with the most landslides per unit area of exposure is the Lawrence Formation (table 2). This finding agrees with the general perception of the Lawrence Formation as one of more landslide-prone rock units in northeast Kansas (F. Wilson, personal communication, 1997; D. Thompson, personal communication, 1999). After the Lawrence Formation, the most susceptible units are the Atchison formation, the Oread Limestone, and the Kanwaka Shale.

The distribution of slope angles within a geologic unit's outcrop area also affects the susceptibility ranking of each unit. Glacial drift is located at the tops of hills and in the western portion of the study area where gentle slopes dominate. The Lawrence Formation is located at the base 


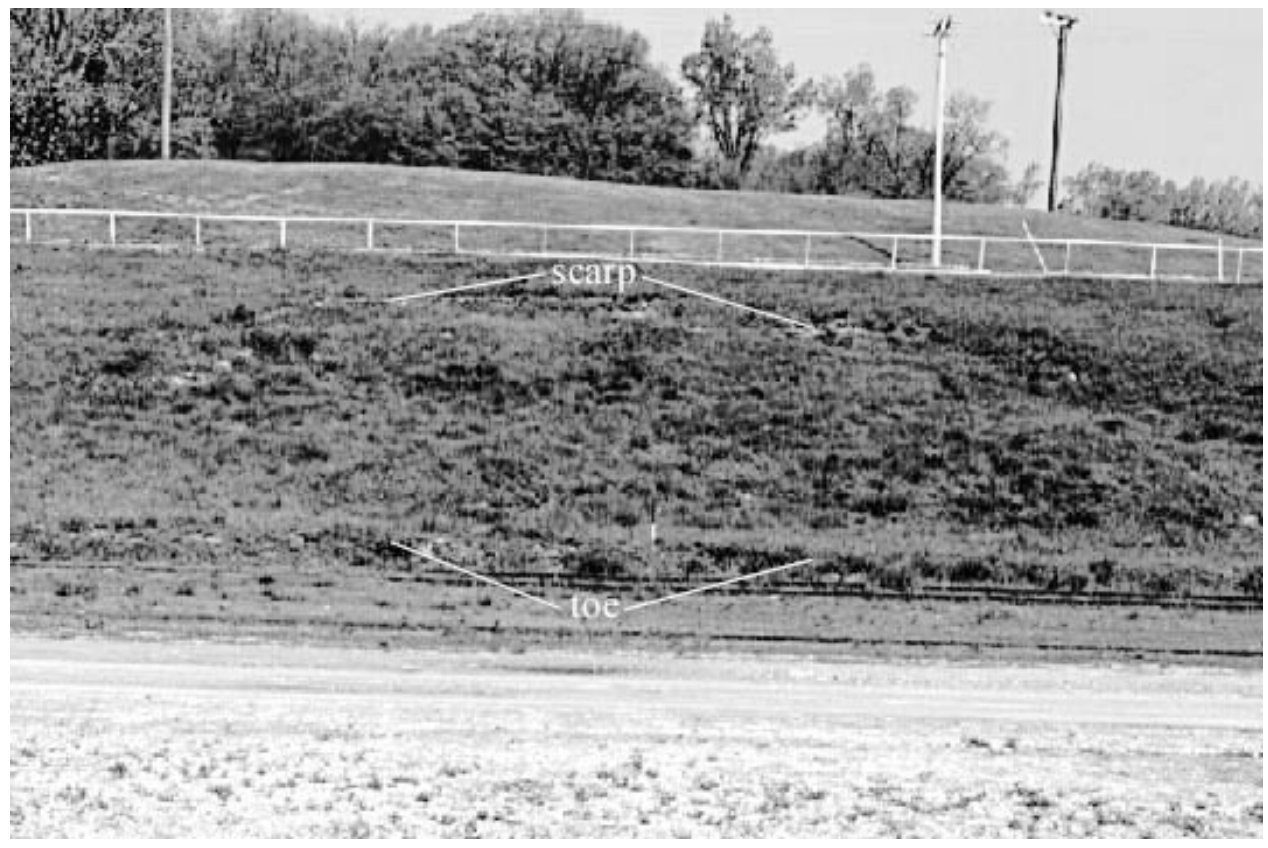

FigURE 11. An earth flow at the U.S. Army underground storage facility in the south end of Atchison, Kansas (SW SE sec. 7, T. 6 S., R. 21 E.).

of the Missouri River bluffs where steep slopes dominate. Thus, the Lawrence Formation is in an area that is more prone to landslides because of slope angle. It would have been advantageous to normalize the number of landslides (table 2) by the area of exposure on slopes grater than 5 degrees, which is the minimum slope angle for landslides in the study area. However, the required slope data are currently unavailable.

Because the Oread Limestone has two limestone members with thicknesses of $2 \mathrm{~m}$ ( $6.4 \mathrm{ft}$ ) or more, it should be resistant to landslides. In the study area, however, the Oread Limestone is the third most susceptible rock unit, based on both the percentage of landslides and the landslides per unit area (table 2). Some of this is due to the fact that parts of the Oread Limestone were incorporated into landslides that involved the Lawrence Formation and Kanwaka Shale. Additionally the Snyderville Shale Member is a 3.8-m-thick (12.5-ft-thick) shale unit near the base of the Oread Limestone (table 1). Small landslides have been observed in the Snyderville Shale in Douglas County. The presence of the susceptible shales surrounding and within the Oread Limestone causes this formation to be susceptible to landslides.

The Atchison formation is composed of alluvium and is the second most important unit on the landslides per unit area list (table 2). The Atchison formation is exposed primarily along the south side of White Clay Creek (table 2 ). The exposure area is small, but the number of landslides is significant yielding a high value for the landslides per unit area. White Clay Creek flows at the base of the bluff where the Atchison formation is exposed. Thus, the landslides in the Atchison formation are the result of undercutting by White Clay Creek, and the susceptibility of the Atchison formation may be slightly lower on slopes that are not being undercut.

No recent landslides were mapped in the Calhoun Shale and the Topeka Limestone. The exposure area of these two formations is small ( $0.6 \%$ of the total study area), and the slopes in the exposure area are gentle. It is unknown whether these two units are involved in recent landslides in other portions of Atchison County. All the remaining units have at least one recent landslide, and thus it seems reasonable to assume that all the rock units could fail under the right conditions.

Shale units were associated with a high percentage of the recent landslides. Twenty-six shale samples were collected from outcrops by removing the upper weathered material to a depth where the shale showed clear bedding. Nonetheless, the samples should still be considered partially weathered. Additionally, a bias exists for collecting the fine-grained portions of the shale units. Thus, the data presented are not representative of the whole unit; for example, the Kanwaka Shale contains sand layers that were not sampled as part of the study.

The shale samples were subjected to a variety of soil analyses (table 3). They were analyzed for Atterberg limits - that is, the water-content boundaries between the semiliquid and plastic states (called the liquid limit) and between the plastic and semisolid states (called the plastic limit) (Jackson, 1997). Based on their Atterberg limits, most samples were classified as clays of low plasticity (CL) and clays of high plasticity (CH), using the Unified Soil Classification System (USCS) (table 3). CL and CH soils have the behavior of clays due to the minerals present but may not necessarily contain high concentrations of clay-sized particles. 
Table 2. Geologic units and recent landslides in the vicinity of Atchison, Kansas.

\begin{tabular}{|c|c|c|c|c|}
\hline Geologic unit & $\begin{array}{l}\text { Number of } \\
\text { landslides }\end{array}$ & $\begin{array}{l}\text { Percentage of } \\
\text { landslides }\end{array}$ & $\begin{array}{c}\text { Area of exposure } \\
(\mathbf{k m 2})\end{array}$ & $\begin{array}{c}\text { Landslides per } \\
\text { unit area of exposure } \\
(1 / \mathbf{k m} 2)\end{array}$ \\
\hline Quaternary alluvium & 6 & $3.3 \%$ & 38.73 & 0.16 \\
\hline loess & 7 & $3.8 \%$ & 29.40 & 0.24 \\
\hline glacial drift & 30 & $16.3 \%$ & 98.78 & 0.30 \\
\hline Atchison formation & 7 & $3.8 \%$ & 0.27 & 25.64 \\
\hline Topeka Limestone & 0 & $0 \%$ & 0.14 & 0 \\
\hline Calhoun Shale & 0 & $0 \%$ & 0.94 & 0 \\
\hline Deer Creek Limestone & 1 & $0.5 \%$ & 6.79 & 0.15 \\
\hline Tecumseh Shale & 17 & $9.2 \%$ & 10.69 & 1.59 \\
\hline Lecompton Limestone & 8 & $4.4 \%$ & 6.42 & 1.25 \\
\hline Kanwaka Shale & 57 & $31.0 \%$ & 7.68 & 7.42 \\
\hline Oread Limestone & 28 & $15.2 \%$ & 2.15 & 13.02 \\
\hline Lawrence Formation & 23 & $12.5 \%$ & 0.39 & 58.97 \\
\hline Totals & 184 & & & \\
\hline
\end{tabular}

Table 3. Soil analyses performed on 44 samples.

\begin{tabular}{|c|c|c|c|c|c|c|}
\hline \multirow[t]{2}{*}{ Rock Unit } & \multicolumn{3}{|c|}{ Atterberg limits } & \multirow[t]{2}{*}{ USCS } & \multirow{2}{*}{$\begin{array}{c}\text { Specific } \\
\text { Gravity }\end{array}$} & \multirow[t]{2}{*}{ Activity } \\
\hline & $\begin{array}{c}\text { Liquid } \\
\text { limit }\end{array}$ & $\begin{array}{c}\text { Plastic } \\
\text { limit }\end{array}$ & $\begin{array}{c}\text { Plasticity } \\
\text { index }\end{array}$ & & & \\
\hline \multicolumn{7}{|l|}{ alluvium } \\
\hline landslides & $41.7-54.6$ & $19.0-21.2$ & $21.0-36.9$ & $\mathrm{CH}, \mathrm{CL}$ & 2.74 & $0.71-1.90$ \\
\hline loess & $27.0-50.2$ & $18.3-23.2$ & $4.2-31.1$ & $\mathrm{CL}, \mathrm{ML}, \mathrm{CH}$ & & $0.50-0.94$ \\
\hline "Nortonville clay" & $61.7-66.2$ & $17.2-17.9$ & $43.7-49.0$ & $\mathrm{CH}$ & & $0.99-1.08$ \\
\hline glacial drift & $32.1-59.2$ & $13.6-18.2$ & $18.4-41.1$ & $\mathrm{CH}, \mathrm{CL}, \mathrm{SC}$ & & $0.80-1.34$ \\
\hline \multicolumn{7}{|l|}{ Atchison formation } \\
\hline \multicolumn{7}{|l|}{ Topeka Limestone } \\
\hline Calhoun Shale & 49.6 & 22.5 & 27.2 & $\mathrm{CL}$ & 2.73 & 0.74 \\
\hline Deer Creek Limestone & $37.4-60.1$ & $18.4-24.0$ & $19.0-36.1$ & $\mathrm{CH}, \mathrm{CL}$ & $2.75-2.85$ & $0.71-0.86$ \\
\hline Tecumseh Shale & 41.2 & 25.8 & 15.4 & ML & & 0.74 \\
\hline \multicolumn{7}{|l|}{ Lecompton Limestone } \\
\hline Kanwaka Shale & $36.2-65.1$ & $21.2-26.1$ & $15.1-39.0$ & $\mathrm{CH}, \mathrm{CL}$ & $2.74-2.83$ & $0.43-0.84$ \\
\hline \multicolumn{7}{|l|}{ Oread Limestone } \\
\hline Lawrence Formation & $35.3-53.5$ & $18.9-22.2$ & $16.4-31.2$ & $\mathrm{CH}, \mathrm{CL}$ & $2.74-2.82$ & $0.50-0.70$ \\
\hline
\end{tabular}

Table 4 shows that a high percentage of clay-sized fragments were observed in the Kanwaka Shale (up to $87 \%$ clay), the Lawrence Formation (up to $68 \%$ ), and in recent landslides (up to 65\%). Expansive clays were found in the clay minerals of the Kanwaka Shale. Expansive clays increase in volume as the moisture content increases. This leads to the degradation of the rock structure and the formation of soil from the shale (Ingram, 1953). Additionally, the expansive nature of the clays can weaken the soil, as the moisture content increases.

Six samples from the Kanwaka Shale were analyzed for their clay mineralogy using X-ray Diffraction (XRD), and two samples were reanalyzed by K/T Geoservices to verify the results. All the samples contained a poorly crystallized, expandable material that included mixedlayer illite/smectite. Two samples contained an expandable mixed-layer chlorite/smectite. One sample contained some $\mathrm{Ca}$-montmorillonite, which is expansive but not as expansive as Na-montmorillonite. Nonexpansive clay minerals in the samples include illite, kaolinite, and chlorite.

The results of the XRD analysis were extrapolated to samples from other units by examining the Atterberg limits. The position that the Atterberg limits plot on a plasticity chart can be related to the clay mineralogy of a soil (Casagrande, 1948; Holtz and Kovacs, 1981). In this study, the liquid limit and plasticity index for each sample were plotted on a plasticity chart, which contained the ranges for montmorillonite, illite, kaolinite, and chlorite 
Table 4. Gradation for 44 samples of shale and unconsolidated units.

\begin{tabular}{|c|c|c|c|c|c|}
\hline \multirow[t]{2}{*}{ Rock unit } & \multirow[b]{2}{*}{ Gravel } & \multicolumn{2}{|c|}{ ASTM gradation } & \multirow[b]{2}{*}{ Clay } & \multirow{2}{*}{$\begin{array}{r}\text { Number o } \\
\text { samples }\end{array}$} \\
\hline & & Sand & Silt & & \\
\hline alluvium & & & & & 0 \\
\hline landslides & $0.4-12.6$ & $2.2-8.0$ & $32.4-56.0$ & $29.0-65.0$ & 5 \\
\hline loess & 0 & $0.3-10.0$ & $59.6-79.0$ & $11.0-39.8$ & 6 \\
\hline "Nortonville clay" & 0 & $1.5-4.5$ & $45.0-49.0$ & $49.5-50.0$ & 2 \\
\hline glacial drift & $0-6.5$ & $28.5-55.4$ & $17.5-36.7$ & $24.0-35.4$ & 5 \\
\hline Atchison formation & & & & & 0 \\
\hline Topeka Limestone & & & & & 0 \\
\hline Calhoun Shale & 0 & 6.0 & 38.0 & 56.0 & 1 \\
\hline Deer Creek Limestone & 0 & $5.0-8.0$ & $38.0-59.0$ & $33.0-57.0$ & 4 \\
\hline Tecumseh Shale & 0 & 7.5 & 59.0 & 33.5 & 1 \\
\hline Lecompton Limestone & & & & & 0 \\
\hline Kanwaka Shale & $0-7.8$ & $0.1-18.2$ & $12.8-60.9$ & $32.5-87.0$ & 12 \\
\hline Oread Limestone & & & & & 0 \\
\hline Lawrence Formation & $0-4.0$ & $1.0-8.0$ & $29.8-58.5$ & $39.5-68.0$ & 8 \\
\hline
\end{tabular}

(fig. 12). Montmorillonite is an expansive clay mineral in the smectite group. The plasticity chart shows that the samples are composed of a mixture of montmorillonite and illite with some samples near each clay mineral. These results are in agreement with the XRD analysis of the six samples presented above. Underwood (1967) states that shales with clay fractions containing illite and montmorillonite have lower shear strengths and higher swelling potentials and are more prone to landslide problems than shales composed of kaolinite and chlorite.

Activity values for the samples were also calculated (table 3). Activity is defined as the plasticity index divided by the percentage of clay-sized fragments in a sample (Skempton, 1953). Shales with activity values greater than 0.75 are prone to landslide problems (Underwood, 1967). With the exception of the Lawrence Formation, all the other geologic units tested had at least one sample with an activity value close to or greater than 0.75 , indicating that all of these units can contribute to landslide problems.

\section{Soils and landslides}

The relationship between NRCS soil series and landslides is given in table 5. The greatest number of landslides, 79, occurred in Gosport soils, which develop on moderate to steep slopes underlain by bedrock. On the other hand, Martin and Vinland soils, which develop on bedrock, were involved in only 1 landslide each. Armster soils had 25 landslides and developed on moderate slopes underlain by glacial drift. Shelby soils, which also developed on glacial drift, had 6 landslides. KnoxGosport and Knox soils had 15 and 7 landslides, respectively. Knox soils developed on moderate slopes underlain by loess, and Knox-Gosport soils are a mixture of the Knox and Gosport soil series. Sharpsburg soils, which also developed on loess, have 1 landslide. Kennebec and Haynie soils, which develop on alluvium, have 5 and 4 landslides, respectively. None of the other
NRCS soil series in the study area had any landslides.

The data presented in table 5 show that soils developed on bedrock are the most susceptible to landslides. This agrees with the geologic data that showed a high percentage of landslides in bedrock (table 2). The next highest percentage of landslides is in soils developed on glacial drift, followed by soils developed on loess and alluvium. The NRCS soil maps include the Atchison formation with soils developed on the glacial drift. Thus, the landslides in the Atchison formation are included with the landslides in glacial drift in table 5.

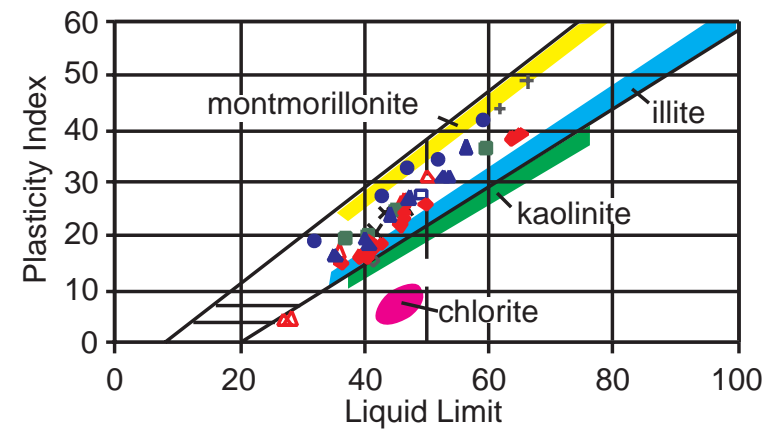

FIGURE 12. A plasticity chart showing the relationship of the soil samples to clay mineralogy. The figure includes samples from the Lawrence Formation (blue triangles), the Kanwaka Shale (red diamonds), the Tecumseh Shale (black open diamond), the Deer Creek Limestone (green squares), the Calhoun Shale (blue open squares), glacial drift (blue circles), the "Nortonville Clay" (black pluses), loess (red open triangles), and landslides (black crosses). The points where Atterberg limits plot on plasticity charts relate to the dominant clay mineralogy of the sample (Casagrande, 1948; Holtz and Kovacs, 1981). The Atterberg limits of the Atchison samples plot in the area between montmorillonite, a smectite clay, and illite, with some samples having more illite and others more montmorillonite. 


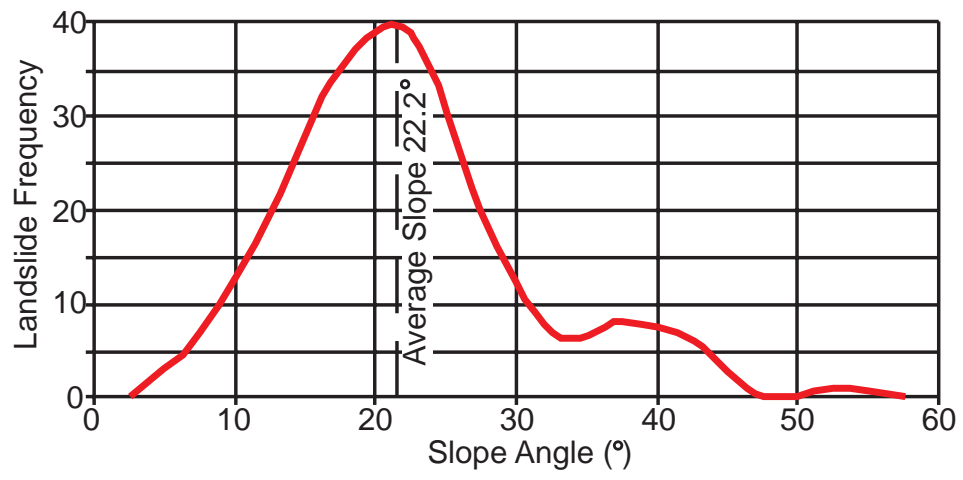

FIGURE 13. The frequency of recent landslides for a given slope angle. The frequencies were determined by counting the number of landslides for 5-degree intervals of slope angle. The average slope angle for recent landslides is 22.2 degrees.

Slope angles and landslides

The slope angle for each of the 145 recent landslides was determined from the U.S. Geological Survey topographic maps. The slope angle is the angle between the horizontal and the ground surface. Figure 13 relates the frequency of landslides to the slope angle. The average slope angle for landslides is 22.2 degrees with $75 \%$ of the landslides on slopes greater than 15 degrees. One landslide is on a slope of only 5.7 degrees.

Landslides on slopes with low slope angles highlight the role clay layers within the shale formations play in slope stability. Above the Clay Creek Limestone Member of the Kanwaka Shale is a $20-\mathrm{cm}$ (8-in) clay layer, with a high percentage of clay-sized particles and expansive clay minerals. In the Jackson Park area, several recent land- slides were mapped above the Clay Creek Limestone, placing the failure planes of the landslides in the $20-\mathrm{cm}$ clay layer (fig. 14). As fig. 14 shows, the portion of the failure surface that runs through the clay layer has a very low dip. This and other thin clay layers may be controlling some of the recent landslides, including those on gentle slopes ( 5 degrees to 15 degrees).

Figure 13 shows a decrease in frequency of recent landslides on slopes greater than 22 degrees. This decrease may result from the fact that steep slopes tend to have thinner soils and that the percentage of the area with steep slopes is relatively small. The steepest slopes are in limited areas along the bluffs of the Missouri River and its tributaries. Normalization of the data to the percentage of the area with the various ranges of slope angle may

Table 5. Soil units and landslides.

\begin{tabular}{|c|c|c|c|}
\hline Soil unit & $\begin{array}{c}\text { Parent } \\
\text { material }\end{array}$ & $\begin{array}{c}\text { Number } \\
\text { of landslides }\end{array}$ & $\begin{array}{c}\text { Percentage } \\
\text { of landslides }\end{array}$ \\
\hline Gosport & bedrock & 79 & $54.5 \%$ \\
\hline Armster & glacial drift & 25 & $17.2 \%$ \\
\hline Knox-Gosport & bedrock \& loess & 15 & $10.3 \%$ \\
\hline Knox & loess & 7 & $4.8 \%$ \\
\hline Shelby & glacial drift & 6 & $4.1 \%$ \\
\hline Kennebec & alluvium & 5 & $3.5 \%$ \\
\hline Haynie & alluvium & 4 & $2.8 \%$ \\
\hline Martin & bedrock & 1 & $0.7 \%$ \\
\hline Sharpsburg & loess & 1 & $0.7 \%$ \\
\hline Vinland & bedrock & 1 & $0.7 \%$ \\
\hline Aquents & alluvium & 0 & $0 \%$ \\
\hline Chase & terrace & 0 & $0 \%$ \\
\hline Grundy & loess & 0 & $0 \%$ \\
\hline Judson & alluvium & 0 & $0 \%$ \\
\hline Onawa & alluvium & 0 & $0 \%$ \\
\hline Pawnee & glacial drift & 0 & $0 \%$ \\
\hline Reading & terrace & 0 & $0 \%$ \\
\hline Wabash & alluvium & 0 & $0 \%$ \\
\hline unknown & & 1 & $0.7 \%$ \\
\hline Totals & & 145 & \\
\hline
\end{tabular}




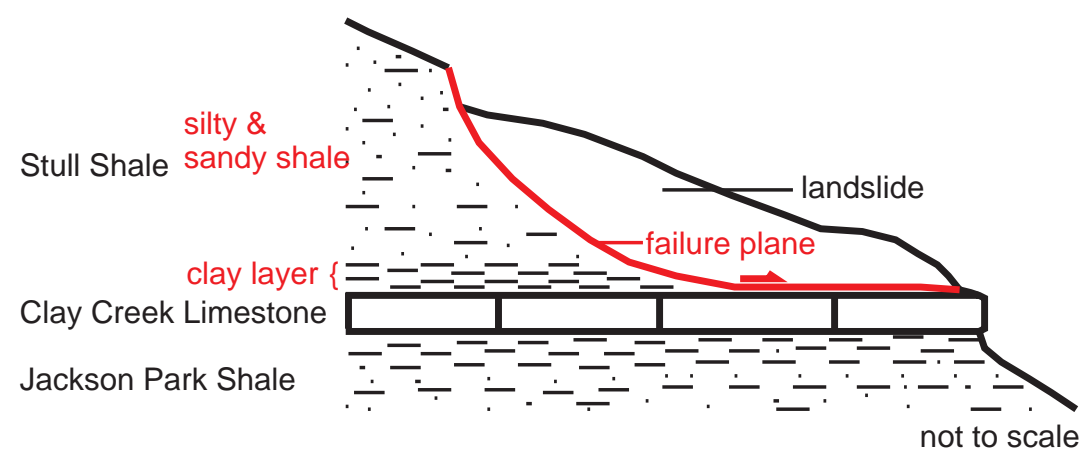

FIGURE 14. Diagram of the failure plane of a landslide in the Kanwaka Shale. The clay layer above the Clay Creek Limestone Member is weak, and the failure plane of the landslide would be located within this layer. Earth slides and earth flows on gentle slopes ( 5 degrees to 15 degrees) may be the result of thin, weak clay layers.

provide a more realistic assessment of the role of slope angle in landsliding, but the slope data required for doing the normalization were not available when this report was written.

\section{Slope line and landslides}

According to conventional wisdom, landslides are more likely to occur on slopes with slope lines to the north (north-facing slopes). The hypothesis is that less direct sunlight and slightly cooler temperatures lead to less evaporation and more moisture in the soils on north-facing slopes. Slope lines for the recent landslides are plotted in fig. 15. Two maxima are observed in figure 15. The first ranges from the northeast to southeast and coincides with the slope lines for the Missouri River bluffs (the yellow area in fig. 15). The second maximum is to the northwest.

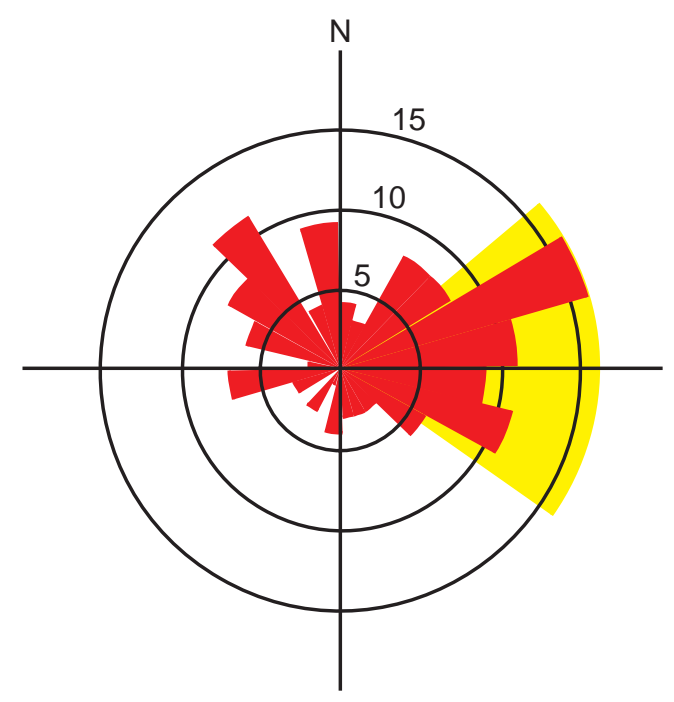

FIGURE 15. Rose diagram showing the slope lines for the recent landslides. Two maxima are observed in the data. The first is from northeast to southeast and is related to the bluffs of the Missouri River (yellow area in figure). The second is to the northwest and may be related to ground-water flow.
This is partially due to the fact that Deer, White Clay, and Walnut creeks tend to flow along the southern side of their valleys, eroding the toe of the northwest-facing slopes. Ground-water flow may also contribute to landslides on slopes with slope lines to the northwest. Precipitation that infiltrates at the top of a hill migrates down until it reaches an impermeable layer and then flows above the impermeable layer to the face of the hill. An example of an impermeable layer is the clay layer above the Clay Creek Limestone Member (fig. 14). Bedrock in the study area dips very gently to the northwest and west (fig. 7). When ground water reaches the impermeable layer, it would flow to the northwest and exit on slopes with slope lines to the northwest, west, and north, increasing the susceptibility of these slopes to landslides.

\section{Conclusions}

The key factors contributing to landslide problems in the study area include slope angle, hydrology, geology, soils, and slope line. Rock-fall and rock-topple hazards are associated with areas of exposed limestone-especially areas where exposed limestones overlie shales that are being eroded. Recent landslides, which are dominantly earth slides and earth flows, generally occurred in bedrock and soil developed on bedrock, but almost every rock unit mapped in the area had at least one recent landslide. Shale formations were more susceptible than limestone formations to slope failures; however, weak shale members of limestone formations can also cause problems. Recent landslides occurred on moderate to steep slopes, but some are found on gentle slopes (5 degrees to 15 degrees). Recent landslides were most likely to occur on slopes with either southeast to northeast or northwest orientations. The Lawrence Formation was the most landslide prone unit.

Thin (less than $0.3 \mathrm{~m}$ or $1.0 \mathrm{ft}$ ) clay layers within the shale formations and the shale members of limestone formations play an important role in causing landslides. These layers have a high percentage of clay-sized particles, which include expansive clays. Thus, these layers 
are planes of weakness and can become the failure planes of landslides. Additionally, these clay layers, along with the clays in the siltstones and residuum from weathering the limestone, are sources of clay minerals to the soil.

Landslide hazards should be considered in the planning and design phases of construction in the Atchison area. This is particularly important in such areas as the bluffs along the Missouri River and its tributaries that have exposed or subsoil shale units. Many options exist for mitigation and remediation of landslide hazards. The best is to avoid areas that are susceptible to landslides. It is recommended that a qualified geotechnical or civil engineer with the assistance of a geologist examine the slopes and make recommendations. It is also important that the recommendations of the engineer be followed.

\section{Acknowledgments}

The author would like to thank Charles Baskerville, Helen Delano, John Gosse, John Moylan, and Charles Cammack for their helpful and insightful reviews. Additional thanks go to Mike Magnuson for the X-ray diffraction work at the Kansas Geological Survey.

\section{References}

Aber, J. S., 1991, The glaciation of northeastern Kansas: Boreas, v. 20, p. 297-314.

Carson, M. A., 1976, Mass-wasting, slope development, and climate; in, Geomorphology and Climate, E. Derbyshire, ed.: London, John Wiley and Sons, p. 101-136.

Casagrande, A., 1948, Classification and identification of soils: Transactions of the American Society of Civil Engineers, v. 113, p. 901-930.

Condra, G. E., 1927, The stratigraphy of the Pennsylvanian System in Nebraska: Nebraska Geological Survey, Bulletin 1, $291 \mathrm{p}$.

Cruden, D. M., 1991, A simple definition of a landslide: Bulletin of the International Association of Engineering Geology, v. 43 , p. 27-29.

Cruden, D. M., and Varnes, D. J., 1996, Landslide types and processes; in, Landslides Investigation and Mitigation, A. K. Turner and R. L. Schuster, eds.: National Research Council, Transportation Research Board, Special Report 247, p. 36-75.

Dreeszen, V. H., and Burchett, R. R., 1971, Buried valleys in the lower part of the Missouri River Basin; in, Pleistocene stratigraphy of Missouri River Valley along the KansasMissouri Border, C. K. Bayne, H. G. O'Connor, S. N. Davis, and W. B. Howe, eds.: Kansas Geological Survey, Special Distribution Publication 53, p. 21-25.
Frye, J. C., 1941, Reconnaissance of ground-water resources in Atchison County, Kansas: Kansas Geological Survey, Bulletin 38 , pt. 9 , p. $237-260$.

Frye, J. C., and Leonard, B., 1952, Pleistocene Geology of Kansas: Kansas Geological Survey, Bulletin 99, 230 p.

Helyar, T., ed., 1999, Kansas Statistical Abstract 1998: Lawrence, Kansas, The University of Kansas, 467 p.

Holtz, R. D., and Kovacs, W. D., 1981, An Introduction to Geotechnical Engineering: Englewood Cliffs, New Jersey, Prentice-Hall, 733 p.

Ingram, R. L., 1953, Fissility of mudrocks: Geological Society of America, Bulletin 64, p. 869-878.

Jackson, J. A., ed., 1997, Glossary of Geology (4 ${ }^{\text {th }}$ Edition): Alexandria, Virginia, American Geological Institute, 769 p.

Kehew, A. E., 1995, Geology for Engineers and Environmental Scientists (2nd ed.): Englewood Cliffs, New Jersey, Prentice Hall, 574 p.

Moore, R. C., Frye, J. C., Jewett, J. M., Lee, W., and O'Connor, H. G., 1951, The Kansas Rock Column: Kansas Geological Survey, Bulletin 89, 132 p.

Ohlmacher, G. C., 1999, Geologic map of the Atchison West and East 7.5-minute quadrangles, Atchison County, Kansas: Kansas Geological Survey, Open-file Report 99-38, scale $1: 36,000$.

2000, Landslide inventory map of the Atchison West and East 7.5-minute quadrangles, Atchison County, Kansas: Kansas Geological Survey, Map M-89A, scale 1:36,000.

Price, J. M., 1896, Rock exposures about Atchison: Transactions of the Kansas Academy of Science, v. 14, p. 218-219.

Sallee, K. H., and Watts, C. E., 1984, Soil Survey of Atchison County, Kansas: United States Department of Agriculture, Soil Conservation Service, $105 \mathrm{p}$.

Sharpe, C. F. S., 1938, Landslides and Related Features-A Study of Mass Movements of Soil and Rock: New York, Columbia University Press, $137 \mathrm{p}$.

Skempton, A. W., 1953, The colloidal activity of clays; in, Proceedings of the Third International Conference on Soil Mechanics and Foundation Engineering: Zurich, Switzerland, ICOSOMEF, p. 57-61.

Thornbury, W. D., 1954, Principles of Geomorphology: London, John Wiley and Sons, 618 p.

Underwood, L. B., 1967, Classification and identification of shales: Proceedings of the American Society of Civil Engineers, Journal of the Soil Mechanics and Foundations Division, v. 93, SM6, p. 97-116.

Varnes, D. J., 1978, Slope movement types and processes; in, Landslides Analysis and Control, R. L. Schuster and R. J. Krizek, eds.: National Research Council, Transportation Research Board, Special Report 176, p. 11-33.

Ward, J. R., 1973, Geohydrology of Atchison County, northeastern Kansas: U.S. Geological Survey, Hydrologic Investigations Atlas HA-467, 2 maps.

West, T. R., 1995, Geology Applied to Engineering: Englewood Cliffs, New Jersey, Prentice Hall, 560 p.

Wieczorek, G. F., 1996, Landslide triggering mechanisms; in, Landslides Investigation and Mitigation, A. K. Turner and R. L. Schuster, eds.: National Research Council, Transportation Research Board, Special Report 247, p. 76-90.

Zey, J. J., and Ferguson, E. G., 1995, Subsurface Exploration and Engineering Evaluation, Riverview Road Slope Failure: Topeka, Kansas, GeoSystems Engineering, Inc., 13 p. (plus appendices). 